\title{
The effect of self management on consumptive behavior in students
}

\author{
Asni Asni ${ }^{\left.{ }^{*}\right)}$, Najma Mega Wangi ${ }^{1}$, Nur Aini ${ }^{1}$ \\ ${ }^{1}$ Universitas Muhammadiyah Prof. DR.Hamka, Indonesia
}

\begin{tabular}{l}
\hline Article Info \\
\hline Articlehistory: \\
Received Jun $12^{\text {th }}, 201 \mathrm{x}$ \\
RevisedAug $20^{\text {th }}, 201 \mathrm{x}$ \\
AcceptedAug $26^{\text {th }}, 201 \mathrm{x}$
\end{tabular}

Keyword:

Self Management.

Consumptive behaviour

\begin{abstract}
This research is motivated by the existence of consumptive behavior among students. This condition occurs because students tend to respond to various changes in the world of fashion. Consumptive behavior can be overcome by increasing self-management to control consumptive behavior. This study aims to determine the effect of self-management on consumptive behavior. The research method used is a quantitative method using a simple random sampling technique to 95 students. The instruments used were consumptive behavior instruments and self-management instruments. The number of instrument items used was 75 items that met the requirements for the validity and reliability of the instrument. Analysis of the data used in this study using inferential statistical analysis.
\end{abstract}

\section{CorrespondingAuthor:}

Asni Asni,

Universitas Muhammadiyah Prof. DR.Hamka

Email: asnicaniago99@gmail.com

\section{Introduction}

The era of globalization creates various kinds of problems that must be faced by every individual in the fields of education, economy, social and culture (Indriyanti, 2018; Kadarisman, 2017; Tidjani, 2017). The form of the influence of globalization with rampant consumptive behavior in the community(Anggraeni, 2019; Miranda \& Lubis, 2017; Nani \& Mohamad, 2020; Prasetya, Hijrah, \& Boer, 2020). Globalization, apart from changing lifestyles, also affects individual habits and perspectives(Estuningtyas, 2018; Garis, 2018; Inayati, 2019; Ohy, Kawung, \& Zakarias, 2020). This phenomenon of consumptive behavior is also influenced by technological developments so that habits and lifestyles are formed that are more modern, such as the rise of online shopping sites.(Sari, 2020).

Consumptive behavior is a globalization phenomenon that is often found in urban communities(Aryani, 2006; Octaviani \& Kartasasmita, 2018; Tripambudi \& Indrawati, 2020). This condition is also influenced by the fact that individuals have their own needs for life. As for meeting these needs, individuals have different ways. There are individuals who meet their needs naturally and others fulfill them excessively. This is what causes many people to adopt a consumptive lifestyle(Astuti, 2013; Dikria \& Mintarti, 2016; Fitria, 2015; Patricia \& Handayani, 2014).

The main actors of consumptive behavior are the late adolescence and early adulthood age groups(Ulayya \& Mujiasih, 2020). Teens who are classified as consumptive in their age range 16-21 because product purchases are based on prestige and self-esteem(Chrisnawati \& Sri, 2011; Mustika \& Astiti, 2017). Based on the research above, this is closely related to the characteristics of those who are easily persuaded by fun things, join friends, want to get social recognition from many people and tend to be wasteful in using money. These characteristics are easily utilized by producers to become marketing targets for various industrial products(Sofiana \& Indrawati, 2020). So that ultimately encourages them to engage in consumptive behavior. 
Another thing also shows that the current consumptive lifestyle is centered on the western world, where starting from technology, fashion, to places to eat. describes the lifestyle patterns of the western world that pervade Indonesian teenagers, especially in big cities(Asmita \& Erianjoni, 2019; Siti Maryam, Yusuf, \& Baining, 2020; Susilowati, 2019). This consumptive lifestyle can continue to take root in the lives of teenagers(Susilowati, 2019);(Devi Adibah \& Harianto, 2019);(Azizah \& Listiara, 2017), where in their development without them knowing it, they develop into adults with a consumptive lifestyle (Nani \& Mohamad, 2020).

Kotler argues that consumptive attitudes can arise because individuals are less able to distinguish between needs, wants and requests (Chrisnawati \& Sri, 2011; Fadhilah, 2018). Therefore we as humans must have a good planning of life goals. Planning a good life goal is not easy, because we must be able to be consistent with what has been planned. Planning a good life goal, including by implementing self management.

Self Management is a strategy in which humans direct their own behavior (Ayu Lestari \& Nursalim, 2019; Dinda Lestary \& Winingsih, 2020; Nurismawan \& Winingsih, 2020; Safithry \& Anita, 2019). The point here is, how a human being is able to control themselves in the thoughts, words and actions that they will do so that later they can avoid things that are considered not good and they can do what they should.Self management also refers to the ability to achieve a goal, harmony of thought, speech and action (Goddess \& Gratitude, 2020) so that what is thought is the same and in line with what is said and done.

In addition, what is meant by self management here is a procedure in which individuals regulate their own behavior (Komalasari, 2016). Because one form of self-management attitudes and behaviors in adolescents, namely being able to apply a frugal and simple lifestyle in themselves, for example being able to control online shopping behavior (Ardiyanti, 2020; Kholida, 2019). Because basically in adolescents there is a desire to get all what they want, while meeting their needs adolescents still need money from their parents or other adults.

The fact is that today many teenagers are caught in the tide of experimenting or joining in with friends. Often times, teenagers in choosing and buying something do not think about the benefits(Ilham, 2017), meaning that adolescents are still unable to determine which are the basic needs and which are less important needs. This is certainly not very good for teenagers because with it they will buy things that they think are good but do not see what are the advantages and benefits of these items. Therefore, self management is needed in everyday life, so that we can control ourselves well. People whose selfmanagement is not good, they will be easily influenced by changing circumstances and easily influenced by others so they tend not to focus on their own life goals.

In this case, students who are an individual transition from the adolescent phase to the adult phase(Lybertha \& Desiningrum, 2017; Oetari, 2017). As for this phase, students tend to have consumptive behavior due to lifestyle changes(Solihat \& Arnasik, 2018) starting from the school level to college, for example, starting to use smartphones (Siregar, 2018) and have lots of free time (Fajar \& Sadewi, 2020). This phase change is of course inseparable from the various influences of consumptive behavior. Because it is usually in this phase that individual characteristics are easily persuaded by things that are considered pleasant(Badriyyati, 2020)and in the end they are the main actors of the consumptive lifestyle itself. Students who have consumptive behavior tend not to be able to control this behavior(Galih Priyambodo \& Khisbiyah, 2020; Tripambudi \& Indrawati, 2020).

Based on a preliminary study in the form of distributing questionnaires to 40 students of BK UHAMKA class of 2017, it was found that there were several students of BK FKIP UHAMKA class of 2017 who engaged in consumptive behavior. This can be seen from the results of the questionnaire, namely there are 11 people who have low self-management and low consumptive behavior, 4 people who have low selfmanagement and high consumptive behavior, 16 people who have high self-management and low consumptive behavior, and the last 9 people. who have high self-management and high consumptive behavior. From the results of the questionnaire found 13 students who have high consumptive behavior. However, if seen, of the 13 students, 4 students with high consumptive behavior have low self-management, and 9 students who have high consumptive behavior also have high self-management. These students are said to be carrying out consumptive behavior because it is seen from the habits of those who like to shop online and shop in person. Unfortunately, they buy these items not based on need but only to fulfill their wishes, join friends and are tempted by discounts on these items.

This is of course very inversely proportional to the existing statements. Because ideally, individuals who have high self-management are able to control themselves in consumptive behavior(Kholida, 2019). Therefore, researchers are very interested in conducting this research in more depth. Based on the results of 
the preliminary studies that have been conducted, researchers are interested in knowing the effect of self management on consumptive behavior at the student level. In connection with this problem, researchers are interested in examining the effect of self management on the consumptive behavior of BK FKIP UHAMKA students.

\section{Method}

Based on the problems, problem boundaries and research objectives, this type of research is quantitative with associative techniques. The sampling technique in this study using simple random sampling technique with a sample of 92 students. The instrument in this study used the Guttman scale for consumptive behavior variables and the Likert scale for self management variables. The analysis requirements test was carried out to determine whether data analysis could be continued or not in a study. In this study, researchers used two statistical tests, namely the normality test and simple linear regression test between the independent variables and the dependent variable.

\section{Results and Discussion}

This research donefor BK students class 2017, with a sample size of 92 respondents, consisting of 82 $(89.1 \%)$ women and $10(10.9 \%)$ men. The number of samples was taken from a total population of 120 students using the simple random sampling technique. The results of data calculation can be interpreted as having an influence self managementon the consumptive behavior of students of Guidance and Counseling FKIP UHAMKA class of 2017. The results of calculations carried out using Pearson Product Moment analysis, obtained $\mathrm{r}=0.40$, the correlation value of this size is sufficient, obtained $\mathrm{t}$ count $=97.420$ and $\mathrm{t}$ table $=1.973$ with a significant level $\alpha=0.05$ with a contribution of $16 \%$. Because $t$ count $>t$ table, it can be concluded that there is a significant influence between self-management variables and consumptive behavior. Self management has a positive impact on consumptive behavior.

Table 1. Hypothesis Test Results

\begin{tabular}{ccccc}
\hline $\mathbf{t}_{\text {count }}$ & $\mathbf{t}_{\text {table }}$ & $\mathbf{D K}$ & Criteria & Information \\
\hline $\mathbf{9 7 , 4 2 0}$ & 1,973 & 182 & $\mathrm{t}_{\text {count }} \mathrm{t}_{\text {table }}$ & Significant \\
\hline
\end{tabular}

The results of the t-test calculation shown in the table above show that tcount $=97.420>$ ttable 1.973 . So based on the testing criteria, Ho is rejected and HI is accepted. The conclusion is that the research hypothesis is accepted, which states the influence of self management on consumptive behavior onStudent of BK FKIP Muhammadiyah University Prof. Dr. Hamka, class of 2017.

Based on the results of the research, the students of BK FKIP Uhamka class of 2017 have stable selfmanagement in managing themselves. This can be seen from the balanced percentage between each existing indicator. The highest percentage of self-management is found in the indicator of how they understand the learning material easily, which is $8 \%$, which means that the student's level of self-management is moderate and positive. This is certainly not easy if students are unable to control themselves to stay focused on learning activities. Therefore, to be able to control their thoughts, students are asked to be able to control themselves well.

Judging from the percentage results above, the highest percentage of consumptive behavior is found in the indicator of buying products to maintain appearance and prestige, namely $34 \%$. This happens because BK students class 2017 tend to have the desire to mingle and be accepted in their peer group environment. So, some of them think that in order to be accepted into the play group, they have to adjust to the group(Destisya, Hendarso, \& Yusnaini, 2019; Sudarto, 2020) One of them is in terms of appearance and lifestyle (Lodeng, 2018; Risnawati \& Wardoyo, 2018). Individuals buy something not based on benefits, but they buy something so that they are not considered out of date(Alwer, 2017; Solichah \& Kusuma Dewi, 2019). This kind of behavior, of course, if left unchecked, will make it difficult for students to organize themselves and in the end their consumptive behavior will increase.

As explained above, that self management has a sufficient influence on consumptive behavior. This can be seen fromThe level of contribution of self-management to consumptive behavior is only around $16 \%$, which causes that the influence of self-management on consumptive behavior is at a sufficient level. This can 
be understood because there are other factors that influence the consumptive behavior of students such as the environment, lifestyle(Khairat, Yusri, \& Yuliana, 2018) and the state of the economy (Kurniawan, 2019; Oktafikasari \& Mahmud, 2017). These two things are considered to be a bridge for students to engage in consumptive behavior, because they will be easily influenced by existing conditions and added to the fact that if their economic situation is sufficient, they will easily engage in consumptive behavior.

The opinion above is supported by the results of research by Triyaningsih (2011) which explains other factors that influence consumptive behavior (Triyaningsih, 2011): (1) The factor of the presence of advertising, producers use effectiveness to attract consumers, advertising is very effective in influencing people to try and ultimately buy products from these producers. (Kurniawan, 2019). Advertising influences consumers to purchase goods that are purely desirable(Wasundari \& Atmosphere, 2019), not based on irrational needs and prices; (2) Conformity factor, conformity is more likely to occur in adolescents, especially girls(Alma, 2018; Ernayanti \& Marheni, 2019), conformity occurs because of a demand to appear attractive and the same as the group, with the aim of being recognized by the group(Anjani \& Astiti, 2020); (3) Lifestyle factor, buying branded and luxury goods will increase one's social status(Anggraini \& Santhoso, 2017; Melina \& Wulandari, 2018; Windayani \& Astiti, 2020)

Kotlerargues that a consumptive attitude can arise because individuals are less able to distinguish between needs, wants and interests. Therefore we as humans must have a good planning of life goals(Chrisnawati \& Sri, 2011). good goal planning is not easy, because we must be able to be consistent with what has been planned. Planning a good life goal should be by applying self management. However, it turned outself managementhas an influence on consumptive behavior by $16 \%$, which means that $84 \%$ is influenced by other variables. One of them is like self-control. Self-control is a human act in fostering a determination to discipline the will, stimulate enthusiasm, erode reluctance, and exert energy to actually do what must be done.(Gie, 2004). All plans that have been set, there is no point if an individual cannot control his determination and exert his strength to carry out and complete various goals in his life. In addition, consumptive behavior is also influenced by the environment, if someone's environment is not good, then the possibility of supporting someone to behave consumptively.

The results of this study are also in line with research conducted by Titia Herawati (2016) entitled The Effect of Work Procedures and Self-Management on Work Safety for Employees of PT. Alam Jaya Pratama. In this study, it was found that there was an influence between self-management and work safety on employees of PT. Alam Jaya Pratama(Herawati, 2016). This means that the higher the self-management in employees, the higher the safety of employees, on the contrary, if there is no safety at work, the employees have low self-management.

Based on the analysis of the research results, it can be concluded that the self-management of the students of BK FKIP UHAMKA class of 2017 is positive self-management and the consumptive behavior of students is included in moderate consumptive behavior. The effect of self-management on consumptive behavior is $16 \%$. Thus $84 \%$ is influenced by other variables or factors.

\section{Conclusion}

Conclusion of research results about influenceself-management on consumptive behavior in UHAMKA FKIP Guidance and Counseling students, namely, there is an effect of self-management on consumptive behavior in UHAMKA FKIP Guidance and Counseling students. Owned self managementcollege studentBK FKIP UHAMKA is positive self management and student consumptive behavior is included in moderate consumptive behavior. The effect of self-management on consumptive behavior is $16 \%$. Thus $84 \%$ are influenced by other factors. Based on the analysis of the mean graph, it shows that self management is at a medium level approaching high, while consumptive behavior is at a moderate level nearing low. This shows that if there is an increase in self management, there will be a decrease in consumptive behavior. Therefore there is an influence on both of these variables. That is, if the higher the self-management of the BK FKIP UHAMKA students, the lower the consumptive behavior.

\section{References}

Alma, Y. (2018). Konformitas dengan Kepercayaan Diri pada Remaja Komunitas Pecinta Korea di Pekanbaru. Psikoislamedia: Jurnal Psikologi, 2(2), 212-223.

Alwer, M. N. (2017). Hubungan antara Gaya Hidup Hedonis dengan Perilaku Konsumtif Fashion pada Mahasiswi Universitas Mercu Buana Yogyakarta. Universitas Mecu Buana Yogyakarta. 
Anggraeni, Y. L. (2019). Perubahan perilaku konsumtif pada buruh pabrik: Penelitian di Desa Cangkuang Kecamatan Rancaekek Kabupaten Bandung. UIN Sunan Gunung Djati Bandung.

Anggraini, R. T., \& Santhoso, F. H. (2017). Hubungan antara Gaya Hidup Hedonis dengan Perilaku Konsumtif pada Remaja. Gadjah Mada Journal of Psychology (GamaJoP), 3(3), 131-140.

Anjani, P. S., \& Astiti, D. P. (2020). Hubungan kontrol diri dan konformitas terhadap perilaku konsumtif remaja penggemar animasi Jepang (anime) di Denpasar. Jurnal Psikologi Udayana, 144-155.

Ardiyanti, N. I. (2020). Teknik self management melalui terapi syukur untuk mengurangi kecanduan belanja online pada seorang remaja di Desa Campurejo Panceng Gresik. UIN Sunan Ampel Surabaya.

Aryani, G. (2006). Hubungan Antara Konformitas Dan Perilaku Konsumtif Pada Remaja di SMA Negeri I Semarang Tahun Ajaran 2005/2006. Universitas Negeri Semarang.

Asmita, D., \& Erianjoni, E. (2019). Perilaku Konsumtif Mahasiswi dalam Mengikuti Trend Fashion Masa Kini (Studi Kasus Mahasiswi Sosiologi FIS UNP). Jurnal Perspektif, 2(2), 91-96.

Astuti, E. D. (2013). Perilaku konsumtif dalam membeli barang pada ibu rumah tangga di Kota Samarinda. Psikoborneo, 1(2).

Ayu Lestari, F., \& Nursalim, M. (2019). Layanan Konseling Kelompok Strategi Self-Management untuk Meningkatkan Kontrol Diri Terhadap Kedisiplinan Siswa Kelas XI SMA Negeri 11 Surabaya. Jurnal BK UNESA, 10(2).

Azizah, P. N., \& Listiara, A. (2017). Hubungan antara konformitas dengan perilaku konsumtif dalam pembelian tas melalui online shop pada mahasiswi Fakultas Ilmu Sosial dan Ilmu Politik (FISIP) dan Fakultas Ilmu Budaya (FIB) Universitas Diponegoro. Empati, 6(1), 332-337.

Badriyyati, H. (2020). Teknik Biblioterapi sebagai Upaya Meminimalkan Perilaku Konsumtif pada Siswi Kelas XI SMAN 1 Boyolangu. IAIN Tulungagung.

Chrisnawati, D., \& Sri, M. A. (2011). Faktor-Faktor Yang Mempengaruhi Perilaku Konsumtif Remaja Terhadap Pakaian. Jurnal Spirits, 2(1).

Destisya, J., Hendarso, Y., \& Yusnaini, Y. (2019). Peran Peer Group dalam Membentuk Perilaku Konsumtif Mahasiswa Fakultas Ekonomi, Universitas Sriwijaya. Jurnal Sosiologi Nusantara, 5(2), 126139.

Devi Adibah, I., \& Harianto, S. (2019). Gaya Hidup Remaja Santri Nongkrong di Kafe. Paradigma, 8(1).

Dewi, F. S. K., \& Syukur, Y. (2020). Existential-Humanistic Counseling Approach to Improve Self Management in Students. Journal of Counseling, Education and Society, 1(2), 47-52.

Dikria, O., \& Mintarti, S. U. (2016). Pengaruh Literasi Keuangan Dan Pengendalian Diri Terhadap Perilaku Konsumtif Mahasiswa Jurusan Ekonomi Pembangunan Fakultas Ekonomi Universitas Negeri Malang Angkatan 2013. Jurnal Pendidikan Ekonomi, 9(2), 128-139.

Dinda Lestary, Y., \& Winingsih, E. (2020). Penerapan Konseling Kelompok dengan Strategi Self Management untuk Mengurangi Kecanduan Media Sosial Siswa di SMAN 1 Driyorejo. Jurnal BK UNESA, 11(3).

Ernayanti, N. M. D., \& Marheni, A. (2019). Peran Konformitas Teman Sebaya dan Self Monitoring Terhadap Impulsive Buying pada Remaja Madya Putri di Denpasar. Jurnal Psikologi Udayana, 226-236.

Estuningtyas, R. D. (2018). Dampak Globalisasi Pada Politik, Ekonomi, Cara Berfikir Dan Ideologi Serta Tantangan Dakwahnya. Al-MUNZIR, 11(2), 195-218.

Fadhilah, F. N. (2018). Pengaruh Gaya Hidup Konsumtif Dan Beauty Vlogger Sebagai Kelompok Referensi Terhadap Keputusan Pembelian Kosmetik Studi Kasus Pada Remaja Perempuan Pengguna Kosmetik Korea Di Surabaya. Jurnal Ilmu Manajemen, 7(1), 133-142.

Fajar, C., \& Sadewi, P. Z. A. (2020). Analisis Perilaku Konsumtif Mahasiswa Penerima Beasiswa Bidikmisi IAIN Surakarta Angkatan 2017. Academica: Journal of Multidisciplinary Studies, 4(1), 81-98.

Fitria, E. M. (2015). Dampak online shop di instagram dalam perubahan gaya hidup konsumtif perempuan shopaholic di Samarinda. Jurnal Ilmu Komunikasi, 1(3), 117-128.

Galih Priyambodo, A., \& Khisbiyah, Y. (2020). Hubungan Antara Self-Control Dan Kecenderungan Kepribadian Narsistik Dengan Perilaku Konsumtif Pada Mahasiswa Fakultas Ilmu Ekonomi Dan Bisnis Universitas Muhammadiyah Surakarta. Universitas Muhammadiyah Surakarta.

Garis, R. R. (2018). Kepemimpinan pemerintahan pada era globalisasi (kajian tentang kepemimpinan pemerintahan di indonesia). Moderat: Jurnal Ilmiah Ilmu Pemerintahan, 4(1), 1-11.

Gie, L. (2004). Cara Belajar yang Baik Bagi Mahasiswa: Yokyakarta. Yogyakarta: Gajah Mada Press.

Herawati, T. (2016). Pengaruh Prosedur Kerja dan Manajemen Diri Terhadap Keselamatan Kerja Pada Karyawan PT. X. Psikoborneo: Jurnal Ilmiah Psikologi, 4(3).

Ilham, F. (2017). Peranan sikap do it yourself (DIY) dalam meminimalisir perilaku konsumtif di kalangan remaja (studi kasus di Desa Banjaran Kabupaten Bandung). FKIP Unpas.

Inayati, N. (2019). Dampak Globalisasi terhadap Perubahan Gaya Hidup pada Masyarakat Kampung 
Komboi Distrik Warsa Kabupaten Biak Numfor. Gema Kampus IISIP YAPIS Biak, 14(2), 32-40.

Indriyanti, A. (2018). Peningkatan Mutu Dalam Manajemen Sdm Untuk Daya Saing Perguruan Tinggi Di Era Globalisasi. Prima Ekonomika, 8(1).

Kadarisman, M. (2017). Tantangan Perguruan Tinggi dalam Era Persaingan Global. Sociae Polites, 3-20.

Khairat, M., Yusri, N. A., \& Yuliana, S. (2018). Hubungan Gaya Hidup Hedonis dengan Perilaku Konsumtif pada Mahasiswi. Al-Qalb: Jurnal Psikologi Islam, 9(2), 130-139.

Kholida, N. (2019). Konseling pra nikah dengan teknik self management dalam mengatasi perilaku konsumtif pada seorang calon pengantin wanita di desa Kraton Krian Sidoarjo. UIN Sunan Ampel Surabaya.

Komalasari, G. (2016). Teori dan Teknik Konseling. Jakarta: Indeks.

Kurniawan, C. (2019). Analisis Faktor-Faktor yang Mempengaruhi Perilaku Konsumtif Ekonomi pada Mahasiswa. Jurnal Media Wahana Ekonomika, 13(4).

Lodeng, A. (2018). Pengaruh Gaya Hidup Hedonis terhadap Perilaku Konsumtif Menurut Ekonomi Islam (Studi Pada Mahasiswa Santri Ma'had Al-Jami'ah UIN Raden Intan Lampung). UIN Raden Intan Lampung.

Lybertha, D. P., \& Desiningrum, D. R. (2017). Kematangan Emosi Dan Persepsi Terhadap Pernikahan Pada Dewasa Awal: Studi Korelasi pada Mahasiswa Fakultas Hukum Universitas Diponegoro. Empati, 5(1), 148-152.

Melina, A., \& Wulandari, S. (2018). Pengaruh Literasi Ekonomi dan Gaya Hidup Terhadap Perilaku Konsumtif Mahasiswi Pendidikan Ekonomi STKIP YPM Bangko. SJEE: Scientific Journals of Economic Education, 2(1), 141-152.

Miranda, S., \& Lubis, E. E. (2017). Pengaruh instagram sebagai media online shopping fashion terhadap perilaku konsumtif mahasiswi Fakultas Ilmu Sosial Dan Ilmu Politik Universitas Riau. Riau University.

Mustika, F., \& Astiti, D. P. (2017). Gambaran Pengambilan Keputusan Remaja Putri Dalam Perilaku Belanja Online. Jurnal Psikologi Udayana, 4(2), 379-389.

Nani, U., \& Mohamad, K. (2020). Kajian Riset Mengenai Pendidikan Islam yang Berorientasi pada Isu-Isu Sosial sebagai Dampak Globalisasi. Jurnal Al-Amar (Ekonomi Syariah, Perbankan Syariah, Agama Islam, Manajemen Dan Pendidikan), 1(4), 51-61.

Nurismawan, S., \& Winingsih, E. (2020). Penerapan Konseling Individu Strategi Self-Management untuk Mengurangi Perilaku Kecanduan Menonton Drama Korea pada Peserta Didik Kelas X MIA 7 SMA Negeri 2 Lamongan. Jurnal BK UNESA, 11(3).

Octaviani, C., \& Kartasasmita, S. (2018). Pengaruh Konsep Diri Terhadap Perilaku Konsumtif Pembelian Produk Kosmetik Pada Wanita Dewasa Awal. Jurnal Muara Ilmu Sosial, Humaniora, Dan Seni, 1(2), 126133.

Oetari, R. (2017). Hubungan Antara Pemaafan dengan Psychological Well-Being pada Mahasiswa Fakultas Psikologi Universitas.

Ohy, G., Kawung, E. J. R., \& Zakarias, J. D. (2020). Perubahan Gaya Hidup Sosial Masyarakat Pedesaan Akibat Globalisasi Di Desa Rasi Kecamatan Ratahan Kabupaten Minahasa Tenggara. HOLISTIK, Journal Of Social and Culture.

Oktafikasari, E., \& Mahmud, A. (2017). Konformitas Hedonis dan Literasi Ekonomi terhadap Perilaku Konsumtif Melalui Gaya Hidup Konsumtif. Economic Education Analysis Journal, 6(3), 684-697.

Patricia, N. L., \& Handayani, S. (2014). Pengaruh gaya hidup hedonis terhadap perilaku konsumtif pada pramugari maskapai penerbangan "X." Jurnal Psikologi Esa Unggul, 12(1), 127078.

Prasetya, W., Hijrah, L., \& Boer, K. M. (2020). Efek Terpaan Belanja Online melalui Instagram di Komunitas Pasar Setan dalam Membentuk Perilaku Konsumtif Masyarakat Kota Samarinda. eJournal Ilmu Komunikasi, 8(3), 153-166.

Risnawati, R., \& Wardoyo, C. (2018). Pengaruh Pendidikan Ekonomi Keluarga, Gaya Hidup, Modernitas Individu, dan Literasi Ekonomi terhadap Perilaku Konsumtif Siswa. Jurnal Pendidikan: Teori, Penelitian, Dan Pengembangan, 3(4), 430-436.

Safithry, E. A., \& Anita, N. (2019). Konseling Kelompok Dengan Teknik Self Management Untuk Menurunkan Prasangka Sosial Peserta Didik. Suluh: Jurnal Bimbingan Dan Konseling, 4(2), 33-41.

Sari, V. R. (2020). Fenomena Gaya Hidup Masyarakat Kontemporer dalam Era Belanja Daring. JSSH (Jurnal Sains Sosial Dan Humaniora), 4(1), 55-62.

Siregar, M. (2018). Hubungan antara Harga Diri dengan Perilaku Konsumtif terhadap Smartphone pada Mahasiswa. Jurnal Psikologi, 10(2).

Siti Maryam, E., Yusuf, M., \& Baining, M. E. (2020). Pengaruh Perubahan Trend Jilbab dan Ketertarikan Fashion Berjilbab terhadap Perilaku Konsumtif pada Mahasiswi UIN STS Jambi. UIN Sulthan Thaha Saifuddin Jambi.

Sofiana, I. I., \& Indrawati, E. S. (2020). Hubungan Antara Harga Diri dengan Perilaku Konsumtif Membeli Kosmetik pada Mahasiswi Jurusan Manajemen Fakultas Ekonomika dan Bisnis Universitas X 
Semarang. Empati, 9(1), 58-64.

Solichah, N., \& Kusuma Dewi, D. (2019). Hubungan antara Konformitas dengan Perilaku Konsumtif terhadap Produk Fashion pada Mahasiswa. Character: Jurnal Penelitian Psikologi., 6(3).

Solihat, A. N., \& Arnasik, S. (2018). Pengaruh Literasi Ekonomi Terhadap Perilaku Konsumtif Mahasiswa Jurusan Pendidikan Ekonomi Universitas Siliwangi. Oikos: Jurnal Kajian Pendidikan Ekonomi Dan Ilmu Ekonomi, 2(1), 1-13.

Sudarto, N. R. (2020). Hubungan Antara Konformitas dengan Perilaku Konsumtif Pada Mahasiswa Ekonomi Stambuk 2018 di Universitas Medan Area. Universitas Medan Area.

Susilowati, W. (2019). Pengaruh perkembangan teknologi terhadap perilaku konsumtif dalam berbusana di kalangan santriwati: studi kasus di Pondok Pesantren Madrosatul Qur'anil Aziziyah Ngaliyan Semarang.

Tidjani, A. (2017). Manajemen Lembaga Pendidikan Islam Menghadapi Tantangan Globalisasi. Reflektika, 12(1), 96-133.

Tripambudi, B., \& Indrawati, E. S. (2020). Hubungan antara kontrol diri dengan perilaku konsumtif pembelian gadget pada mahasiswa teknik industri Universitas Diponegoro. Empati, 7(2), 597-603.

Triyaningsih, S. L. (2011). Dampak online marketing melalui facebook terhadap perilaku konsumtif masyarakat. Jurnal Ekonomi Dan Kewirausahaan, 11(2), 172-177.

Ulayya, S., \& Mujiasih, E. (2020). Hubungan Antara Self Control dengan Perilaku Konsumtif Pengguna EMoney pada Mahasiswa Fakultas Psikologi Universitas Diponegoro. Empati, 9(4), 271-279.

Wasundari, I. A. R., \& Suasana, I. G. A. K. G. (2019). Peran Brand Equity Memediasi Pengaruh Iklan terhadap Keputusan Pembelian Produk Kutus-Kutus di Kota Denpasar. E-Jurnal Manajemen, 8(2), 646672.

Windayani, S., \& Astiti, D. P. (2020). Peran konformitas dan gaya hidup brand minded terhadap perilaku konsumtif mahasiswi di Kota Denpasar. Jurnal Psikologi Udayana, 96-108. 